\title{
Marcin Bielski, Kronika, to jest historyja świata, oprac. Dariusz Śnieżko, Dorota Kozaryn przy współudziale Eleny Karczewskiej, Szczecin 2019, t. 1: ss. 498, t. 2: ss. 640, t. 3: ss. 586
}

\begin{abstract}
Czytelnik odkryje w tej księdze wielką zaiste rozmaitość wydarzeń i postaci, koleje i odmiany rzeczy, mnogie przykłady na zmienność chwiejącej się tam i sam Fortuny, godne podziwu rady i rad tych nieoczekiwane skutki, poważne i odpowiednie do okoliczności wypowiedzi - niczym zwierciadło natury ludzkiej, w którym przegląda się całe życie.
\end{abstract}

M. Bielski, Najjaśniejszemu wtadcy Zygmuntowi Augustowi..., przekł. D. Śnieżko

Choć patrząc z perspektywy czasu jej powstania, Kronika Marcina Bielskiego została przywrócona obiegowi czytelniczemu stosunkowo niedawno, bo w roku $1976 \mathrm{w}$ formie przedruku dokonanego techniką fotooffsetową przez Wydawnictwa Artystyczne i Filmowe, a więc w postaci stanowiącej dokładne odzwierciedlenie ostatniej ogłoszonej za życia autora najpełniejszej edycji z roku 1564 (trzeciej z kolei po wydaniach z lat 1551 i 1554); w ostatnich latach dostępna jest w tejże oryginalnej postaci w Internecie w cyfrowych zbiorach polskich bibliotek, do których zbiorczy dostęp zapewnia Federacja Bibliotek Cyfrowych; to jednak wydanie jej we współczesnej formie graficznej z odpowiednim aparatem edytorskim uznać należy za znaczące wydarzenie wybiegające swym zasięgiem poza krąg badaczy literatury dawnej, historii, języka oraz innych dziedzin zajmujących się poznawaniem i odczytywaniem przeszłości. O trwałym znaczeniu tego dzieła dla kultury polskiej świadczą edycje: Franciszka Bohomolca z roku 1764, ogłoszona w Warszawie przez Antoniego Gałęzowskiego z lat 1829-1833 w Zbiorze Pisarzów Polskich (t. 11-19) i wydana w Sanoku przez Kazimierza Józefa Turowskiego z 1856 roku w ramach Biblioteki Polskiej (z. 55-82). Ze względu na swą wartość i charakter dzieło ukazywało się więc w zaborach rosyjskim i austriackim. Wszystkie bez wyjątku edycje łączy monumentalny rozmach wymuszony znaczną objętością dzieła. Na 
tym bogatym tle pracę Dariusza Śnieżki i Doroty Kozaryn wyróżnia obszerny komentarz, Wstęp wydawców (t. 1, s. 7-42), Stownik wyrazów dawnych (t. 3, s. 451-498) oraz Wykaz nazw geograficznych (t. 3, s. 499-586).

Współcześni wydawcy słusznie obrali za podstawę edycję z roku 1564, ignorując przeróbkę dzieła dokonaną przez syna Marcina, Joachima Bielskiego, opublikowaną w 1597 r. Z uwagi na znaczną objętość materiału, jak również konieczność dołączenia niezbędnego aparatu publikację podzielono na trzy tomy. Pierwszy z nich obejmuje poza wstępem wyłącznie Księgi pierwsze, tom drugi to księgi od wtórych do siódmych, tom trzeci zamyka w sobie księgi od ósmych do dziesiątych oraz wieńczące dzieło elementy ramy utworu, a także wspomniane już słownik i wykaz. Układ edycji oddaje niemalże wiernie strukturę wydania obranego za podstawę. Słusznie pomijają wydawcy podzielony na dwie części i niepełny Rejestr ku najdowaniu rzeczy przedniejszych, choć w dobie odkrycia samoistnej wartości katalogowania niesie on ważne informacje na temat oglądu i klasyfikacji rzeczy istotnych z punktu widzenia mentalności i wizji ładu świata w XVI wieku, o czym mówią też wiele dawne działowe inwentarze bibliotek i katalogi. Ów rejestr wieńczy napisana z rozbrajającą szczerością adnotacja wydawcy bądź autora: „Na wypisanie Moskwy ani na nowy świat niemasz rejestru, napisz sobie" ${ }^{1}$. W publikacji Śnieżki i Kozaryn brakuje niestety mogącego pełnić analogiczną rolę, nieodzownego przecież w każdej dobrej książce o ambicjach naukowych, indeksu osób i postaci. Szkoda, że wydawcy nie poszli tu śladem Julii Radziszewskiej, która ogłosiła w 1978 r. z rękopisu dzieło $O$ początkach, wywodach, dzielnościach, sprawach rycerskich $i$ domowych stawnego narodu litewskiego... Macieja Stryjkowskiego, opatrując je indeksem osób oraz indeksem nazw geograficznych. Służą one nie tylko ustaleniu współczesnych nazw, ale i umożliwiają zlokalizowanie ich w tekście. Śnieżko i Kozaryn zrezygnowali z jakiejkolwiek formy indeksowania tekstu, bowiem odnośników lokalizacyjnych nie posiada nie tylko Wykaz nazw geograficznych, lecz również Stownik wyrazów dawnych. Tym bardziej wydaje się to istotne, że nie uwzględniono w nim wszystkich znaczeń objaśnianych wyrazów, lecz te, które wydawcy uznali za niezrozumiałe. Nieobeznany z dawnym tekstem odbiorca może mieć trudność ze stwierdzeniem, z jakim przypadkiem ma do czynienia: czy ze słowem posiadającym współczesne znaczenie, czy odbiegające od niego. Odpowiedni odnośnik w słowniku pozwoliłby rozwiać wątpliwości. Zestawienie nazw geograficznych służy wyłącznie odciążeniu komentarza, nie pełni roli indeksu. Zestawienia, o których piszę, są standardowo stosowane w edycjach wychodzących w seriach: „Biblioteka Pisarzy Staropolskich”, jak również „Biblioteka Dawnej Literatury Popularnej i Okolicznościowej”. Inni wydawcy powinni naśladować to rozwiązanie. Nie trzeba dodawać, że indeksy znacząco ułatwią pracę badawczą.

W edycji współczesnej zachowano glosy marginesowe, jak i część materiału ilustracyjnego. Podstawa wydania jest bowiem bogato zdobiona drzeworytami całostronicowymi, włamanymi w tekst zajmującymi 1/4 stronicy, niewielkimi medalionami prezentującymi wyobrażone popiersia wzmiankowanych postaci oraz bogato zdobione inicjały - tych wydawcy już nie wprowadzają.

Godną uznania pracą wykonaną przez edytorów jest samo ustalenie tekstu, określenie zasad transkrypcji i wprowadzenie współczesnej interpunkcji. Działania te stanowią konieczną bazę dla dalszych czynności służących uprzystępnieniu dzieła. Pracę tę wykonano z należytą

$1 \quad$ M. Bielski, Kronika, to jest Historia świata na sześć wieków a czterzy monarchije rozdzielona..., Kraków 1564, k. Mmmm v. 
uwagą, o czym świadczy też opis zasad transkrypcji, bo jedynie w tej formie tekst udostępniony został czytelnikom.

Walorem edycji jest umieszczenie komentarza rzeczowego bezpośrednio pod tekstem. Przybliża wzmiankowane postaci, ludy, nawiązania do Biblii i literatury antycznej i późniejszej historycznej, objaśnia niezrozumiałe zwroty. Wątpliwość wzbudza zastosowana segmentacja numeracji przypisów. Wydawcy przyjęli, że będzie się ona odnosiła do zawartości poszczególnych tomów. I tak, w tomie 1 mamy 3739, w 2 tomie 7435, zaś w 3 tomie 5363 przypisy, czyli łącznie 16537 przypisów. O ile taki podział ułatwia ich zsumowanie, o tyle nie upraszcza korzystania z tekstu. By te wartości były niższe, można było podzielić przypisy, odnosząc je do poszczególnych ksiąg.

Docenić należy wartościowy wstęp, który podzielony został na 3 części. Pierwsza omawia najpierw biografię autora i przybliża środowiska intelektualne oraz wojskowe, w jakich się on obracał, potem podaje charakterystykę twórczości z projektowanym kręgiem odbiorczym (propedeutyka i popularyzacja), odnotowuje preferencje wyznaniowe, które zawiodły dzieła Bielskiego w 1604 r. na indeks ksiąg zakazanych. Śnieżko daje też świadectwo znajomości rękopiśmiennych adnotacji poczynionych przez czytelników na marginesach dzieł. Dostrzega ich podobieństwo do współczesnego hejtu. Badacz ukazał swoistość średniowiecznego gatunku, jaki wybrał Bielski, opracowując kronikę uniwersalną. Dokonał analizy porównawczej kolejnych jej trzech wydań, wspomniał przy okazji o niebezpiecznej dla autora usterce w druku polegającej na uczynieniu z rozbójnika Mysowskiego Myszkowskiego, co sugerowało przynależność złoczyńcy do możnego rodu, którego przedstawiciele zażądali głowy kronikarza. Już na tym etapie ujawnia się świadomość wydawców, iż w istocie każdy egzemplarz dzieła jest niepowtarzalny. Bielski uniknął kary śmierci, dowiódłszy na podstawie poprawnego egzemplarza pomyłki w druku. Śnieżko zwrócił też baczną uwagę na niefunkcjonujący w obiegu badawczym, stanowiący część kroniki dokonany wprost z hebrajskiego konsultowany ze specjalistami bardzo wartościowy przekład biblijnej Księgi Eklezjastesa.

Analiza edycji, która stanowiła podstawę omawianego wydania, dotyczy struktury dzieła, opartej na analogicznych opracowaniach zagranicznych dziejopisów, zwłaszcza Johannesa Nauclerusa, Jakuba da Bergamo i Johannesa Cariona. Śnieżko dostrzega wprowadzenie do opisu dziejów „samodzielnych jednostek narracyjnych” urozmaicających dzieje, dla których prezentacji ważna jest zarówno chronologia, jak i następstwo panowania papieży i cesarzy. Dziejopis omawia też historię ruchu protestanckiego oraz przebieg zmagań z Turkami albańskiego bohatera Jerzego Skanderbega. Wzorem wcześniejszych edycji wprowadza też kosmografię, modyfikując jej funkcję. Odseparowuje ona tym razem dzieje powszechne od kronik poszczególnych krajów, jak też Nowego Świata.

Śnieżko omawia również technikę twórczą Bielskiego, w której wiodącą metodą jest kompilacja. Przybliża sposoby postępowania ze źródłami. Czerpiąc z kilku dzieł (Bielski samodzielnie buduje koncepcję przekazu, nie naśladując wiernie swoich źródeł), przeważnie łacińskich, za ich pośrednictwem odsyła autor do informacji podawanych przez innych autorów, których przywołuje jawnie lub ukrywa. Swoją kompilatorską praktykę, właściwą tego typu opracowaniom, ujawnił Bielski w liście dedykacyjnym, który, jak ustalił Śnieżko, zbudowany jest z zapożyczeń pochodzących z pism Erazma z Rotterdamu, Szymona Marycjusza i Pandulfa Collenuccia. Syntetyczna prezentacja tych źródeł, powiązań i odesłań daje wgląd w zrekonstruowany przez wydawców rozległy i złożony łańcuch powiązań i filiacji, jakie następowały między dawnymi tekstami. Śnieżko dowodzi, iż Bielski stosuje sprawdzoną 
metodę postępowania ze źródłami; dodać trzeba, że później praktykowaną też przez Benedykta Chmielowskiego ${ }^{2}$. Zamiast uzgadniać fakty, dociekać do prawdy, zestawia z sobą różne poglądy. Kolejnymi zabiegami stosowanymi przez kronikarza są przekład, streszczanie i parafrazowanie, jak też redukowanie przyswajanych kronice treści do minimum. Obok erudycji ważne jest wzbudzenie zainteresowania odbiorców poprzez wprowadzanie samoistnych narracji. Śnieżko nie tylko rekonstruuje listę źródeł o charakterze ogólnym, lecz także podaje podstawę, na której oparł się Bielski w częściach omawiających szczegółowe zagadnienia, jak choćby dzieje imperium osmańskiego, etnogenezę Słowian, Nowy Świat oraz judaika. W polu zainteresowania Śnieżki znalazły się także sam gatunek kroniki, jak też wielogatunkowość cechująca poszczególne moduły składające się na całość wielotematycznego kompendium. Badacz podjął również temat pochodzenia i funkcji materiału ilustracyjnego; natomiast zasygnalizował jedynie problem istnienia różnic pomiędzy kolejnymi edycjami dzieła. Nie poprowadził szczegółowej prezentacji tych zmian. Śnieżko ma też świadomość modyfikacji, jakich dokonywał autor razem z wydawcą w czasie druku dzieła, które ujawniają się dzięki porównaniu dostępnych egzemplarzy. Dodać należy, że zjawisko to nie jest wyjątkowe w historii staropolskich druków, przeciwnie, to norma ${ }^{3}$.

Śnieżko odnotowuje ponadto przykłady świadectw lektury kroniki u późniejszych literatów staropolskich, podkreślając jej autorytet. Sygnalizuje zjawisko recepcji dzieła dokonywane przez późniejszych kronikarzy, zwłaszcza Aleksandra Gwagnina oraz na wschodzie w Wielkim Księstwie Moskiewskim i południu kontynentu.

Druga część wstępu przynosi omówienie niuansów języka druku. Jak słusznie zauważa Kozaryn, nie jest to język autora, lecz dzieła. Badaczka dostrzegła brak konsekwencji, uchwyciła zróżnicowanie odmian dialektalnych wynikające z udziału w pracach nad dziełem zecerów reprezentujących rozbieżne cechy językowe. Analiza obejmuje konkretne cechy językowe poszczególnych części druku w relacji do języka autora. Badaczka omawia cechy fonetyczne, fleksję, składnię, zróżnicowanie formalne liczebników, przymiotników, czasowników. Kozaryn dostrzega znaczący wpływ łaciny zwłaszcza na składnię. Analizuje też słownictwo, jego pochodzenie, jak i zmiany, np. w zakresie kształtu nazw własnych dokonujące się w poszczególnych częściach dzieła, zjawiska towarzyszące zapożyczaniu form oraz procesowi przekładania z łaciny pewnych partii dzieła. Wniosek, jaki nasuwa się wskutek lektury językowej części wstępu, to powszechny w dziele brak konsekwencji wynikający z metody twórczej (kompilacja, przekład) oraz przygotowania druku przez liczny zespół zecerów, którego członkowie wprowadzali do publikacje własne, często sprzeczne z sobą i językiem autora cechy fonetyczne.

Te wszystkie, bardzo wnikliwe obserwacje wydawców nie przełożyły się niestety w pełni na rozwiązania, jakie przyjęli. Choć ich edycja, jak deklarują w części trzeciej wstępu, ma charakter popularnonaukowy i realizowana jest w formie transkrypcji, zachowano w niej większość, znakomitą większość, zaobserwowanych wahań i niekonsekwencji. Tego typu praktyka bardziej odpowiednia byłaby dla wydania naukowego podającego transliterację. W edycji popularnonaukowej należało przyjąć jednak najczęściej występujące rozwiązania

2 Zob. M. Wichowa, Ksiądz Benedykt Chmielowski jako uczony barokowy, „Napis” 1999, ser. 5, s. 45-56; B. Marcińczak, Historia naturalna w „Nowych Atenach” Benedykta Chmielowskiego [w:] Cztowiek wobec natury - bumanizm wobec nauk przyrodniczych, red. J. Sokolski, Warszawa 2010, s. 181.

3 Zob. R. Grześkowiak, Stary druk jako podstawa edycji krytycznej. Preliminaria [w:] Jak wydawać teksty dawne, red. K. Borowiec, D. Masło, T. Mika, D. Rojszczak-Robińska, Poznań 2017, s. 11-44. 
bądź najbliższe językowi autora dzieła i tylko w szczególnych przypadkach, ilustrujących zjawiska językowe, zachować wahania. Tym bardziej że wydawcy niepodważalnie dowiedli, iż niekonsekwencje są wynikiem pracy zecerów i autorskiej kompilacji. Obecnie otrzymaliśmy edycję w wersji utrwalającej częściowo chaos w sferze języka dzieła. Szczegółowe zasady transkrypcji dowodzą jednak podjęcia szeregu słusznych, zgodnych ze sztuką edycji działań modernizacyjnych.

Ze względu na encyklopedyczny zamysł publikacji szczególne wyzwanie stanowiły liczne i zróżnicowanie tematycznie objaśnienia rzeczowe. Badacze szczegółowo wyliczają obszary, jakich dotyczą. Słusznie wydawcy poniechali aktualizacji w komentarzach i prostowania wiadomości błędnych z punktu widzenia obecnego stanu wiedzy. Edycja podaje wyłącznie podstawę tekstową dla dalszych prac badawczych, nie ma zastępować monografii, studiów i przyczynków, przeciwnie, ma stwarzać dla nich dogodny grunt. Dlatego właściwe jest postępowanie wydawców objaśniających jedynie to, co uważają za niezbędne dla prawidłowego zrozumienia tekstu. Komentarze obejmują też ustalenia ukazujące bezpośrednie i prymarne źródła wiedzy. Szkoda, że wydawcy wyłączyli z objaśnień a priori noty marginesowe. W tym przypadku również należałoby uznać za wzorcową edycję Radziszewskiej. Transkrypcję właściwego tekstu kroniki poprzedza podana w wyborze bibliografia i wykaz skrótów. Objaśnienia załączone do tekstu uznać trzeba za wystarczające, zarazem odpowiednio syntetyczne i adekwatne do treści. Mają charakter językowy, gramatyczny i rzeczowy: historyczny, geograficzny, biblijny, mitologiczny, osobowy, uwzględniający filiacje literackie. Szkoda, że poniechano wprowadzenia odsyłaczy do kwestii już objaśnionych. Ustalenie czy w ogóle dana rzecz była wcześniej tłumaczona z uwagi na obszerność publikacji jest praktycznie niemożliwa przy wzmiankowanym już braku indeksów.

Dobrze dobrany został format publikacji (B5), ponieważ umożliwia pomieszczenie tekstu głównego oraz będących integralną częścią dzieła marginaliów i objaśnień. Dzięki właściwie dobranemu krojowi czcionki, kerningowi i świattu tekst jest przyjazny w lekturze. Brakuje natomiast systemu umożliwiającego lokalizację danego fragmentu skonstruowanego na wzór edycji dzieł klasycznych. Jego wprowadzenie pozwoliłoby zbudować wydajny system odesłań, którym należałoby wzbogacić słownik.

Zarówno słownik, jak i indeks nazw własnych służą odciążeniu komentarza rzeczowego, ułatwić też mają odbiorcy dotarcie do objaśnień pojęć, nazw, słów wielokrotnie powtarzających się. Uwagę zwraca zróżnicowanie objaśnień pomieszczonych w słowniku. W znacznej części przypadków znalazły się tam synonimy form uwzględniające nawet po kilka znaczeń, innym razem wydawcy posługują się definicją, jak choćby w przypadku słowa „ladrowanie pancerz na konia wykonany z kutych blach lub ze skóry” (t. 3, s. 464) albo „libra — jednostka wagi odpowiadająca ok. 360-500 g, funt rzymski" (tamże). Sądzę, że tego typu objaśnienia powinny znaleźć się w przypisach i być opatrzone odsyłaczami w dalszej części tekstu. Ich przygotowanie wymagałoby jednak tytanicznej pracy liczniejszego zespołu, podobnie jak i wprowadzenie odsyłaczy lokalizujących poszczególne słowa.

Zastosowany system odesłań niewątpliwie jest przemyślany. Naczelnym założeniem koncepcji jest w nim ograniczenie do minimum liczby odsyłaczy, stąd rezygnacja z przypominania w przypisach o pojawieniu się jakiegoś problemu uprzednio, przeniesienie części objaśnień rzeczowych do słownika, a także ustanowienie wykazu nazw geograficznych najczęściej z krótkimi objaśnieniami rzeczowymi. Formuła ta, podyktowana oszczędnością 
i ograniczeniem nakładu pracy, odbiega znacznie od zasad stosowanych w ostatnich dziesięcioleciach XX w. i obecnie w edycjach tekstów dawnych. W istocie rzetelnie opracowane indeksy mogłyby wypełnić jeszcze dodatkowy tom.

Docenić należy szczerość wydawców, którzy w drobiazgowych nieraz notach poprzedzających poszczególne części dzieła precyzyjnie określają zastosowaną metodologię transkrypcji, komentarza, zasad doboru haseł w słowniku czy zwłaszcza w Wykazie nazw geograficznych. Godna uznania jest cechująca edycję harmonia między ujęciem literaturoznawczym a optyką i metodologią językoznawczą. Obie perspektywy podporządkowane zostały uprzystępnieniu dzieła odbiorcy. Spodziewać się można, iż podjęte prace nad tekstem kroniki Bielskiego przyniosą monografię języka dzieła, jak i kolejne studia literaturoznawcze dotykające jego swoistości ${ }^{4}$.

Edycję Dariusza Śnieżki i Doroty Kozaryn cechuje wyjątkowa rzetelność, troska o drobiazgi i perfekcyjne prześwietlenie materiału pisarskiego pod względem źródłowym i językowym oraz erudycyjnym. Publikacja przygotowana została jednak z uwzględnieniem wygody wydawców, bez większej troski o komfort odbiorców, którzy chcieliby studiować dzieło z pomocą indeksów i słownika. Nie sposób bowiem prześledzić przy jego pomocy chociażby użycia poszczególnych form wyrazowych czy też nawiązań do twórczości wybranych poprzedników. Owoce tytanicznego trudu wydawców nie są łatwo dostępne dla czytelnika. Edycję przygotowano w ramach projektu Narodowego Programu Rozwoju Humanistyki na lata 2014-2019.

Michat KuRAN

iD https://orcid.org/0000-0002-0378-2453

$4 \quad$ Kronika była już bowiem uprzednio obiektem badań Dariusza Śnieżki, które zaowocowały m.in. monografią „Kronika wszytkiego świata” Marcina Bielskiego. Pogranicze dyskursów (Szczecin 2004). Do najnowszych prac będących pokłosiem badań, które niezbędne były do przygotowania edycji, należy studium Renesansowe modernizacje kroniki uniwersalnej, „Teksty Drugie” 2019, nr 2. 